\title{
"Don't Delay Learning": Igniting Promotion of Pedagogical Transformation Strategies in Early Childhood Care Education
}

\author{
Shawe Thulebona, Nhase Zukiswa and Dube Bekithemba \\ Faculty of Education, School of Social Sciences and Language Education, \\ University of the Free State, South Africa \\ https://orcid.org/0000-0002-8644-6649 \\ https://orcid.org/0000-0003-4557-9880 \\ https://orcid.org/0000-0003-4327-7838
}

\begin{abstract}
The global pandemic COVID-19 has forced traditional teaching pedagogies to meet the new educational demands such as remote learning. The safety measures and regulations of COVID-19, such as social distancing, have challenged all facets of education to transform their pedagogical strategies to mitigate the spread of the pandemic, but the rate has been slow to catch up the lost learning time in Early Childhood Care Education (ECCE). This study, underpinned in critical emancipatory research, responded to two questions: what are the challenges of ECCE in the context of COVID-19 and how ECCE could adapt ways of promoting transformative pedagogical strategies. This article underpins the notion that ECCE practitioners should be equipped with novel technology methodologies that replace traditional face-to-face teaching and learning. However, it is reasonable to believe that face-toface teaching and learning will not be totally replaced by any other new methodology or fads; it will remain important for some years to come, especially in the lower level classes. A hybrid approach of using both the in-person and distance learning strategies for flexibility and manageability by both learners and practitioners seems promising at the moment. In short, this paper explores the challenges to explore promotion of pedagogical transformation strategies in ECCE, and offers some correctives because this will be an ongoing issue for years to come. There are no easy solutions to be packaged in fancy terminology. We argue that the early promotion of transformative pedagogical strategies will assist the children and make the practitioners' work more flexible and understandable.
\end{abstract}

Keywords: early childhood; pedagogical; hybrid approach; correctives; challenges 


\section{Introduction}

The world went into unprecedented trajectories which was ignited by the spread of COVID 19 like bush fires. COVID 19 "was first hinted at in Wuhan city of the Hubei province in the people's republic of China" (Tanhan et al., 2020). In April 2020, "there were slightly over three million confirmed cases of COVID-19, and 211,321 deaths globally" (Roser et al., 2020). The world pandemic reconfigured many facets of life, including the need to rethink the pedagogical approaches used in teaching and learning (Dube, 2020). The global pandemic saw many systems of life halted as a way to curb the spread of the virus. To control the spread of the virus, South African government was the temporary closure of learning sites. The 26th of March 2020 will be remembered in history as a day in which the South African government closed Early Childhood Care Education (ECCE) centres to protect the learners from the virus. However, the ECCE learning sites' closure necessitated the need for pedagogy scholars to rethink alternatives to ensure teaching and learning continued despite the pandemic. With COVID-19 restructuring all facets of life, attention was given to the upper grades of school and the importance of ECCE was overlooked (Neuman \& Powers, 2021). The focus, especially in the South African context, was to find ways in which Grade 12 and university students could save the academic year, so online learning become the ideal mode of learning despite the new, challenging variables involved. While the move was noble, desirable, and doable, it marginalised the ECCE learners, who were not catered for by the Department of Social Development. The Department of Social Development became silent on discussing learning strategies to address the gap created by closing face-to-face learning and the onward movement to online learning. Thus, this paper will focus on the missing participants of the current online learning arrangement: the ECCE learners. To address the needs of this forgotten category of learners, there is an inevitable need to transform the ECCE's pedagogical strategies to resonate with the current trend of teaching and learning in replacing the traditional face-to-face approach. Based on the preceding, we argue that, in light of the COVID-19 pandemic, there is a need for transforming the pedagogical strategies in ECCE to align teaching and learning with global trends such as virtual or online learning.

This paper comes amidst various studies that have been conducted on ECCE and education, such as Makarova and Makarova's (2018, p. 56) study on "blending the pedagogy and digital technology to transform the educational environment. They pointed out that digital technologies infuse the lives of 21st-century learners, and help teachers recognise the instructional potential of these technologies while they seek ways to utilise them in support of learning effectively". They argued that transformation in any field is never easy, especially in education. In their conclusion, they mentioned that "blending digital educational tools with innovative teaching technologies in the teaching and learning process helps trainees improve their skills and gain experience in the following areas: identifying, selecting, and solving a problem" (Makarova \& Makarova, 2018, p. $56)$.

De Sousa et al. (2019) in their study on "Participatory pedagogies, where need of various stakeholders to participate in learning experiences. held that the challenge was on how within the right approach and they concluded "that providing the 
space and time for all to share their voice and insights is vital to recognising participation as the best solution against the abstract nature of the mainstream transmissive pedagogy" (p. 299).

Formosinho and Pascal's (2017) paper titled "Pedagogy development" in Assessment and Evaluation for Transformation in Early Childhood cited John Dew and Paulo Freire's view that as much as there are two pedagogies - transmissive and participatory - the practitioner needs to choose the most relevant that will make a child an active participant while learning. They explained the difference between the two listed examples and chose transmissive pedagogy as the best solution to promoting relevant learning and social cohesion. In contrast, with participatory pedagogy the teacher's role is to organise the environment and observe the child to understand and respond to it. Therefore, during pedagogical strategies transformation, the practitioners need to integrate the two types of pedagogies and develop strategies that will be more appropriate for children at the ECCE.

Manning et al.'s (2017, p. 2) study on ECCE identified that "higher teacher qualifications are related to improvements in supporting children's development, including supporting the language-reasoning experience; supervision, and the scheduling of activities; organisation and room arrangement; providing varied social experiences for children; and creating a warm and friendly environment for interactions". They concluded their research by arguing "that the early childhood sector's professionalisation through more qualified staff may lead to significant gains for children and their families and life-long outcomes that will benefit all of society" (p. 2).

Kuusisto and Garvis' 2020 study on ECCE explained that "due to societal change and the increasingly intensified migration of recent years, most countries are undergoing notable demographic changes. As a result, early childhood education and care (ECEC) has commonalities across the national contexts, with shared values and pedagogy aimed at supporting children in being democratic (p.279)". They concluded their paper by arguing that there is a growing number of ECEC settings due to social change. As a result, the ECEC is often the first societal arena where super-diversity begins. After a thorough review of these previous research, this paper is unique because it argues for the transformation of pedagogical approaches to align them with the new normal characterised by virtual learning as necessitated by the COVID-19 pandemic. It is also unique because it uses decoloniality theory to argue for localised learning strategies that resonate with African ideologies even in online teaching and learning.

This paper is arranged as follows: theoretical framework; the challenges of transforming ECCE in South Africa; how transformation can be achieved at ECCE centres; findings; and conclusion. The following section addresses the theoretical lens of this paper, which is decoloniality.

\section{Theoretical Framework}

This article is underpinned by decoloniality theory. Wanderley and Barros (2018, p. 79) argued that decoloniality theory "has its roots in Latin America under 
leading scholars such as Walter Mignolo, Maldonado-Torres, Quijano, and Dussel". It "was borne out of a realisation that ours is an asymmetrical world order that is sustained not only by the colonial matrices of power but also by the pedagogies and epistemologies of equilibrium that continue to produce alienated Africans" (Ndlovu-Gatsheni, 2013, p. 11). Furthermore, "decoloniality rejects modernity (especially when it contributes to the symmetry of power), which is located on the oppressed and exploited side of the colonial difference, in favour of a decolonial liberation struggle to achieve a world beyond Eurocentric modernity" (Grosfoguel, 2011, n.p.). The struggle of decoloniality scholars is "against the invisible vampirism of imperialism technologies and colonial matrices of power (coloniality) that continue to exist in the minds, lives, languages, dreams, imaginations, religion and epistemologies of modern subjects in Africa and the entire global South" (Ndlovu-Gatsheni, 2013, p. 11). Decoloniality is about "acknowledging that knowledge is produced from a particular dominant space and that individuals think, know, and act from a particular position" (Muthukrishna \& Engelbrecht, 2018, p. 4). With this in mind, decoloniality emancipates us to advocate the importance of ECCE practitioners, who by default or design are marginalised in the learning process despite the significant role in child development. With decoloniality, the paper advocates for transformative pedagogies that address the ECCE learners' lived realities in the context of a new reality such as COVID-19. By couching this paper in decoloniality, there is an impetus for reconfiguring local pedagogies to enhance teaching and learning as opposed to centring learning on Western ideologies, which may have little significance on the ECCE learners (Seehawer, 2018). With this in mind, decoloniality critiques the superficial worldwide spread of Western knowledge and the dominance of Western culture at the expense of local epistemologies. This theory aims to critique, reformulate, and re-envision power, knowledge, and change, which can reconfigure teaching and learning in a time of crisis - such as COVID-19 - through the adoption of localised pedagogies that resonate with ECCE learners in the South African context.

The following section focuses on the challenges of ECCE in South Africa.

\section{The Challenges of Transforming Early Childhood Care Education in South Africa}

This section responds to research question one: what are the challenges faced by the rural ECCE centres during COVID-19? According to Atmore et al. (2012), even prior to the COVID-19 pandemic, the challenges were vast, and they can be classified as socio-economic inequalities, infrastructure, lack of practitioner training, and a lack of parental interest in children's education. The first challenge discussed is the social-economic inequalities.

\subsection{Socio-economic inequalities}

The worldwide pandemic (COVID-19) was a sad reminder that in South Africa, and perhaps the world over, social inequality is real, and the struggle to address it is still far from being over. COVID-19 widened the rich-poor divide in all facets of life, such as education, especially the rural ECCE learners (Buheji et al., 2021). As such, the rural ECCE centres were worst hit by COVID-19 due to low socio-economic disparities. Children with high cultural capital could mitigate the 
lack of face-to-face teaching and learning by embracing technologies and outsourcing private teachers to assist ECCE learners. Furthermore, urban learners with cultural capital could access social media and television, which helped ensure that teaching and learning were not interrupted.

Mahaye (2020) suggested that the South African government believes that digital equipment should be installed in various schools to support technology-based learning by all learners in South Africa. However, the implementation is slow, and when it happens, more urban learners are beneficiaries than rural learners. This implies that rural learners continue to rely on the traditional method of chalk-andboard teaching, which requires that participants must be present in class, a situation that seems far from being possible given the need for social distancing and keeping the number of learners as low as possible to curb the spread of COVID-19. Bearing this in mind, scholars prone to social justice and decoloniality problematise structures that continue to marginalise learners based on their geographical setting and financial strength. While addressing COVID-19, all learners need to be catered for based on both the principle of equality and equity as a counter-hegemonic strategy against a system that undermines and relegates rural students to the periphery of development. To this end, new avenues of learning are indispensable (Mirriahi et al., 2015; Wikramanayake, 2005) to inject hope for social and economically excluded learners despite their geographic location. Informed by the preceding, we submit that the government has an opportunity to address the rich-poor divide in the learning context, which has characterised South Africa over the years (Jedwab et al., 2020). The rural ECCE centres continue to suffer due to socio-economic inequalities, and COVID-19 is a reminder that rural learners face various trajectories which present a double tragedy for them.

\subsection{Lack of infrastructure}

The other challenge faced by rural ECCE learners is the lack of infrastructure to support the teaching and learning amid the COVID-19 pandemic (Anand et al., 2018). Infrastructure includes many things such as building, network, roads and electricity among many other things. In this paper, infrastructure refers to communication networks such as television and internet connectivity to support online learning. As of March 2020, there was a fallacy that all schools were ready to move to online learning automatically, and there was an intentional denial that rural schools were not ready due to lack of infrastructure. Rural schools are in the peripheral experiencing various challenges which among them is access to technology to support teaching and learning in the time of crisis such as COVID 19. This is cemented by Dieltiens (2008, p. 40), who argued that "rural schools certainly have problems particular to them; predicaments which require systemic effort and creative ideas most." The economically disadvantaged South African child cannot access these provisions adequately. Lack of electricity impacts connectivity and access to online learning resources, impeding the novel idea of moving teaching and learning from traditional face-to-face to online learning. This negates, of course, the effective integration of technology among rural learners (Dzansi \& Amedzo, 2014). In addition, Xafis (2020) argued that the disadvantaged rural ECCE learners are further affected by the misdistribution of power, money, and resources, which in decoloniality must be teased, exposed, and challenged to 
produce a world order where both urban and rural leaners are not pushed to the periphery of development by merely being born to rich or low-income families. Thus, this paper calls for a transformation in the social development sector to ensure that rural learners are put into the centre of learning by the equitable distribution of teaching materials and adequate connectivity, which can help support remote learning for all learners.

\subsection{Lack of teacher re-training}

ECCE learners are disadvantaged because of the lack of re-training for educators who are still adjusting to the new normal. The training teachers receive in their initial teacher education does not remain relevant forever, igniting the need for re-training educators to meet the new demands, especially those brought about by the pandemic. The pandemic exposed the need to rethink education by retraining teachers to meet the needs and demands of online teaching and learning (Whalen, 2020). On this note, we agree with the World Bank (2020, p. 10) that "very few classroom teachers have received training in online instructional approaches and tools. If teachers need to support the online learning of their students while schools are closed, they would need to be prepared to do so before the schools are closed". However, in South Africa, there was an incorrect assumption that all educators were ready and equipped with online teaching and learning materials; however, some were clueless on its usage, thus depriving learners of teaching and learning time, especially those in the rural context. Such scenarios dehumanise learners who are saddled with ill-equipped teachers who cannot prepare for the teaching and learning process under the COVID-19 pandemic. This situation is not peculiar to South Africa alone but the world over. König et al. (2020) commented on the German context by arguing that there is a general lack of teacher competence such as in their technological pedagogical knowledge and teacher education learning opportunities about digital teaching and learning. In light of this challenge, ECCE practitioners are inevitably trained to ensure success for teaching and learning in the COVID-19 context (DarlingHammond \& Oakes, 2021). Regarding ECCE, we agree with Hemmeter et al. (2021, p. 206) that the effectiveness of ECCE will likely "require a broad range of professional development activities and support for staff interactions with children".

\subsection{Insufficient parental involvement in children's education}

Another challenge faced by rural ECCE learners is insufficient parental involvement in educational matters due to various reasons. Mishra and Vij (2020) lamented the insufficient parental involvement in supporting teaching and learning, and COVID-19 has worsened the situation. Most rural parents lack the skills, resources, and understanding to support online learning at ECCE centres. South Africa faces the same challenge of lack of infrastructure, especially in the rural context, coupled with poor connectivity and a limited number of devices in a family. Thus, any success of ECCE teaching and learning has one of its variables as parental involvement. This is because parental involvement positively impacts children's holistic development and, therefore, quality ECEC education (Oke et al., 2020). Therefore, parents, guardians, or siblings need to assist these young children with their schoolwork to ensure they are well developed and understand that education is important. While this may be a noble call, it is based on the 
fallacy that parents have to know how to assist in the teaching and learning of ECCE learners. Parents should have a degree of training and enlightenment to assist learners effectively. Thus, it is essential that while the call is there to train the educators on their role in the teaching and learning in ECCE, the department of education should develop a programme where parents can learn the basics of teaching and learning to assist learners. This approach has the potential to transform ECCE in South Africa through professionalising parental involvement.

Considering the challenges, pedagogical adjustment is inevitable to redress the trajectories faced by rural ECCE learners in the COVID-19 context. The following section addresses what we think can help transform teaching and learning among the ECCE learners in rural areas from a decoloniality mindset.

\section{Igniting Transformation of ECCE : No to Delayed Learning}

In this section, we discuss how ECCE can be transformed towards addressing rural learners' lived realities and facing various vulnerabilities that the COVID-19 pandemic has exacerbated. As a result of this, ECCE scholars should continue to probe and suggest ways to improve teaching and learning while staying sensitive to values such as social justice and inclusivity. In this paper, we based arguments for transformation on decoloniality. This theory argues the need to include all people as a counter-strategy against ontological density where people are categorised on race, geographic location, and other forms of exclusion. The first point we discuss in this section is new pedagogical strategies.

\subsection{New Pedagogical Teaching Strategies}

Transformation is essential to the response of trajectories of ECCE teaching and learning in the COVID-19 context. Such transformation is centred on innovative teaching strategies that resonate with the lived realities of rural learners in South Africa. Pedagogical strategies cannot remain constant, and COVID-19 has become a wake-up call for scholars who need to continue with research that can ignite new teaching and learning strategies. In so doing, we agree with Du Plessis and Mestry's (2019, p. 5) observation that "there is a need to put strategies in place to improve the working conditions of teachers and the teaching at rural schools, to improve learner achievement across the rural areas of South Africa". The success of pedagogical transformation has many variables. One variable is that educators need to be lifelong learners and upgrade themselves with new technological innovations in teaching and learning. Life learning should be central to the teaching profession, which translates to confidence, recognition, and emancipation for the educators and the learners. South Africa requires teachers with the highest qualification in ECCE instead of a diploma in teacher education or certificate, which has characterised many ECCE educators. For ECCE to participate in modernity and gain recognition in decoloniality thinking, lifelong learning is inevitable to equip educators with new or emerging trends in teacher education, especially ECCE. Another variable is the willingness to unlearn in order to learn.

In some cases, educators are resistant to changes, especially when perceived as bringing additional workloads, yet such innovation is intended to make the work easier. With this in mind, we agree with Schwartz (2006, p. 450) that "curriculum 
planners, with all good intentions, have compiled volumes of well-conceived educational action plans, choosing specific materials and activities for their preconceived target: curriculum receivers and students, only to find that the curriculum users and teachers are not prepared for the innovations." While this may have a certain degree of validity, we also note Stabback's (2011, p. 2) "observation that curriculum developers need to take into account where a country is, in terms of the current breadth and depth of the curriculum; attainment levels; the quality of teachers; and the range and effectiveness of teaching, learning and assessment practices." Thus, looking at rural ECCE teachers, the government must avail the resources that equate "rural teachers with their counterparts in urban centres. In so doing, teachers need to be empowered in unthreatening ways, as teacher knowledge is the biggest factor in the implementation of the curriculum" (Quyen \& Khairani, 2017, p. 166). While this is very important, rural educators have a responsibility by engaging in a struggle which emancipates them. This struggle can involve many facets, including consistently challenging the department of education to relook into the plights of rural learners. Apart from challenging the department, educators need to be lifelong learners to hear their voices, which is essential for transformation. Also, they need to adopt best practices that have contributed to the development of teaching and learning in the rural areas of some countries in Africa and beyond. In decoloniality thinking, rural ECCE teachers need to participate effectively in their own emancipation, especially adopting new pedagogical strategies such as online teaching and learning, which have become the new normal due to the COVID-19 pandemic.

\subsection{Improvement of Infrastructure for Rural ECCE Centres}

As a developing country, South Africa can enact structures for rural learners to cater to social distancing. This is because South Africa can build schools for urban areas and have the resources to assist rural learners. Through decoloniality, we need to continue to encourage educational authorities to uphold the ontology of rural learners by providing basic infrastructure to enhance teaching and learning. Decoloniality is against the notion of exclusion of rural learners; thus, scholars prone to social justice need to continue to problematise the skewed distribution of resources favouring urban cities. Informed with decoloniality, this paper agrees with Oloruntegbe and Collins' (2011, p.443) view that "successful reforms are initiated from the grassroots (bottom-up), particularly by teachers and learners who have first-hand experience of the realities of online learning" in the COVID19 context.

Infrastructure not only entails building for teaching and learning, but technological support which includes the learning devices and connectivity that support teaching and learning in the COVID-19 era. The transitioning from faceto-face to online learning is inevitable and resonates with the lack of infrastructure, such as connectivity, that not "only places a damper on academic matters but also on strategies implemented in various contexts to fight COVID19" (Dube, 2020, p 140). Thus, any meaningful transformation needs support from the department, which has shown the potential to provide resources, especially in advantaged communities. Thus, in line with the principle of equality and equity, there is a need to prioritise rural learners and ECCE with appropriate infrastructure. The success of this lies in the collective problematisation of rural 
exclusion with an intention to construct conducive learning. It should not only be rural people waging war against exclusion, but anyone who believes in social justice as an ideal principle to ignite a better society for all. Through this, teaching and learning for ECCE are not delayed, and in the process, transformation for the betterment of all.

\subsection{Collaboration with Social Justice-oriented Stakeholders}

There was never a more critical time in human history when collaboration is essential, and a means to ensure the survival of humankind. Following the scourge of the pandemic, countries have shared technology and knowledge of surviving the pandemic, which has caused immense suffering to humankind. This collaboration is inevitable within education to construct meaningful learning conditions and improve rural ECCE learners and educators' conditions. As suggested by Komives et al. (1998, p. 74), "collaboration is purposeful, builds commitment towards positive change, includes people with diverse points of view, and empowers those involved in making decisions that affect their lives and professions." Transformation centres around collaboration and ECCE educators can tap into the various players oriented to social justice to construct meaningful learning for rural learners. Decoloniality reinforces the need for collaboration, but this should be sensitive to social justice inclusion and the rehumanisation of all people. It is against any form of collaboration that subdues the vulnerable members of society. Instead, decoloniality strives for equal presentation for all actors to ignite learning that embraces diversity and appreciates differences. In other words, transformation is essential and ensures that there is no delay in learning for rural ECCE teaching and learning.

\section{Conclusion}

This article discussed the challenges of transforming ECCE in the South African context. The discussion from various literature revealed the different aspects that still need to be considered by ECCE and the government at large. If in South Africa, we are for a solid, quality educational foundation that is equal for all children across cultures and environment, the government needs to take urgent steps to enhance teaching and learning in ECCE centres. This paper is centred on decoloniality and argued that rural learners' challenges should be addressed as an act of rehumanisation and transformation. It ended by noting how the teaching and learning of ECCE can be transformed to achieve excellence in rural learning. Informed by decoloniality, the paper argued that learning must not be delayed further and that collaboration devoid of the suppression of others is an essential step to configure conducive learning conditions for rural ECCE in the COVID-19 context. Finally, in this study, challenges and correctives have been explored, emphasising teamwork among all the stakeholders, including the social justice advocates and government who needs to tackle infrastructure inequalities, especially in the rural centres and impoverished areas. Also, equipping educators with new technologies and methodologies through interactive refresher courses, seminars should be actively pursued. Continued eager development is essential as the paper demonstrates. Socio-economic distractions must be addressed for a quality educational system that honours, respects, and enriches the culture, history, and human dignity for all learners. 
Acknowledgements: This study was made possible through the funding from DHET and EU on Early Childhood Care Education given to the University of the Free State.

\section{References}

Anand, N., Gupta, A., \& Appel, H. (Eds.). (2018). The promise of infrastructure. Duke University Press.

Atmore, E., van Niekerk, L. J., \& Cooper, M. A. (2012). Challenges facing the early childhood development sector. South Africa South African Journal of Childhood Education, 2(1),

$120-139$ https:// sajce.co.za/index.php/sajce/article/view/25/134

Buheji, M., da Costa Cunha, K., Beka, G., Mavric, B., De Souza, Y. L., da Costa Silva, S., Hanafi, M., \& Chetia Yein, T. (2020). The extent of COVID-19 pandemic socioeconomic impact on global poverty. A global integrative multidisciplinary review. American Journal of Economics, 10(4), 213-224. https://doi.org/10.5923/j.economics.20201004.02

Darling-Hammond, L., \& Oakes, J. (2021). Preparing teachers for deeper learning. Harvard Education Press.

De Sousa, J., Loizou, E., \& Fochi, P. (2019). Participatory pedagogies: Instituting children's rights in day to day pedagogic development. European Early Childhood Education Research Journal, 27(3), 299-304. https:// doi.org/10.1080/1350293X.2019.1608116

Dieltiens, V. (2008). As long as the rain still falls we must cultivate: Africanist challenges to liberal education. Journal of Education, 45, 29-42. http://joe.ukzn.ac.za/Libraries/No_45_Dec_2008/\%E2\%80\%9CAs_long_as_the _rain_still_falls_we_must_cultivate_Africanist_challenges_to_liberal_education. sflb.ashx

Dube, B. (2020). Rural online learning in the context of COVID-19 in South Africa: Evoking an inclusive education approach. Multidisciplinary Journal of Educational Research, 10(2), 135-157. https:// doi.org/10.4471/remie.2020.5607

Du Plessis, P. \& Mestry, R. (2019). Teachers for rural schools - a challenge for South Africa. South African Journal of Education, 39(1), 1-9. https://doi.org/10.15700/saje.v39ns1a1774

Dzansi, D. Y., \& Amedzo, K. (2014). Integrating ICT into rural South African schools: Possible solutions for challenges. International Journal of Educational Science, 6(2), 341-348. https://doi.org/10.1080/09751122.2014.11890145

Formosinho, J., \& Pascal, C. (Eds.). (2017). Assessment and evaluation for transformation in early childhood. Routledge.

Grosfoguel, R. (2011). Decolonising post-colonial studies and paradigms of political economy: Transmodernity, decolonial thinking, and global coloniality. Transmodernity: Journal of Peripheral Cultural Production of the Luso-Hispanic World, 1(1), 1-23. https:// escholarship.org/uc/item/21k6t3fq

Hemmeter, M. L., Fox, L., Snyder, P., Algina, J., Hardy, J. K., Bishop, C., \& Veguilla, M. (2021). Corollary child outcomes from the Pyramid Model professional development intervention efficacy trial. Early Childhood Research Quarterly, 54, 204-218. https://doi.org/10.1016/j.ecresq.2020.08.004

Jedwab, R., Khan, A. M., Damania, R., Russ, J., \& Zaveri, E. D. (2020). Pandemics, poverty, and social cohesion: lessons from the past and possible scenarios for COVID-19 (Working Papers 2020-13). The George Washington University, Institute for International Economic Policy. 
Kuusisto, A., \& Garvis, S. (Eds.) (2020). Superdiversity and the Nordic Model in ECEC. Contemporary Issues in Early Childhood: Special issue:. Contemporary Issues in Early Childhood, 21(4) 279-283. https://journals.sagepub.com/toc/ciea/21/4

König, J., Jäger-Biela, D. J., \& Glutsch, N. (2020). Adapting to online teaching during COVID-19 school closure: Teacher education and teacher competence effects among early career teachers in Germany. European Journal of Teacher Education, 43(4), 608-622. https:/ / doi.org/10.1080/02619768.2020.1809650

Komives, S. R., Lucas, N., \& McMahon, T. R. (1998). Exploring leadership: For college students who want to make a difference. John Wiley and Sons.

Mahaye, N. E. (2020). The impact of COVID-19 pandemic on education: Navigating forward the pedagogy of blended learning. Department of Education, KwaZulu-Natal. https:// www.researchgate.net/publication/340899662_The_Impact_of_COVID19_Pandemic_on_South_African_Education_Navigating_Forward_the_Pedagog y_of_Blended_Learning

Manning, M., Garvis, S., Fleming, C., \& Wong, G. T. (2017). The relationship between practitioner qualification and the quality of early childhood education and care environment. Campbell Systematic Reviews, 13(1), 1-82. https://doi.org/10.4073/csr.2017.1

Makarova, E. A., \& Makarova, E. L. (2018). Blending pedagogy and digital technology transform educational environment. International Journal of Cognitive Research in Science, Engineering and Education, 6(2), 57-66. https://doi.org/10.5937/ijcrsee1802057M

Mirriahi, N., Alonzo, D., \& Fox, B. (2015). A blended learning framework for curriculum design and professional development. Research in Learning Technology, 23. https:// doi.org/10.3402/rlt.v23.28451

Mishra, M. R. D., \& Vij, S. (2020). Challenges in synchronous online education during the coronavirus pandemic in the context of developing countries: Parents' perception in Indian urban schools. Solid State Technology, 63(2), 4685-4714. https://solidstatetechnology.us/index.php/JSST/article/view/3415

Muthukrishna, N., \& Engelbrecht, P. (2018). Decolonising inclusive education in lowerincome, Southern African educational contexts. South African Journal of Education, 38(4), 1-11. https://doi.org/10.15700/ saje.v38n4a1701

Ndlovu-Gatsheni, S. J. (2013). Why decoloniality in the 21st century? The Thinker for Thought Leaders, 10-16. https://raps.dut.ac.za/moodle/pluginfile.php/2215/mod_folder/content/0/N dlovu-Gatsheni $\% 202013 \% 20$ -

\%20Why\%20decoloniality\%20in\%20the\%2021st\%20century.pdf?forcedownload $=1$

Neuman, M. J., \& Powers, S. (2021). Political prioritisation of early childhood education in lowand middle-income countries (Policy Research Working Paper No. 9549). World Bank. https://openknowledge.worldbank.org/handle/10986/35145

Oke, A., Butler, J. E., \& O'Neill, C. (2020). Identifying barriers and solutions to increase parent-practitioner communication in early childhood care and educational services: Early Childhood Education Journal,49(2), 283-293. https:/ / eric.ed.gov/?redir=http $\% 3 a \% 2 f \% 2 f d x . d o i . o r g \% 2 f 10.1007 \% 2 f s 10643-020$ 01068-y

Oloruntegbe, K. O., \& Collins, K. M. T. (2011). Teachers' involvement, commitment and innovativeness in curriculum development and implementation. Journal of Emerging Trends in Educational Research and Policy Studies, 2(6), 443-449. http://citeseerx.ist.psu.edu/viewdoc/download?doi=10.1.1.301.5772\&rep=rep1 \&type $=\mathrm{pdf}$ 
Quyen, N. T. D. \& Khairani, A. Z. (2017). Reviewing the challenges of implementing formative assessment in Asia: The need for a professional development program. Journal of Social Science Studies, 4(1), 160-178. https://doi.org/10.5296/jsss.v4i1.9728

Roser, M., Ritchie, H., Ortiz-Ospina, E., \& Hasell, J. (2020, April 27). Coronavirus pandemic (COVID-19). https://ourworldindata.org/coronavirus\#citation

Schwartz, M. (2006). For whom do we write the curriculum? Journal of Curriculum Studies, 38(4), 449-457. https:/ / doi.org/10.1080/00220270500296606

Seehawer, M. (2018). South African science teachers' strategies for integrating indigenous and Western knowledge in their classes: Practical lessons in decolonisation. Educational Research for Social Change, 7(SPE), 91-110. http:/ / dx.doi.org/10.17159/2221-4070/2018/v7i0a7

Stabback, P. (2011). What makes a quality curriculum? UNESCO. http://unesdoc.unesco.org/images/0024/002439/243975e.pdf

Tanhan, A., Yavuz, K., Young, J., Nalbant, A., Arslan, G., Yıldırım, M., \& Çiçek, İ. (2020). A proposed framework based on literature review of online contextual mental health services to enhance wellbeing and address psychopathology during COVID-19. Electronic Journal on Gen Med, 17(6), em254. https://doi.org/10.29333/ejgm/8316

Wanderley, S., \& Amos B. (2018). Decoloniality, geopolitics of knowledge and historic turn: Towards a Latin American agenda. Management and Organisational History, 14, 79-97. https://doi.org/10.1080/17449359.2018.1431551

Whalen, J. (2020). Should teachers be trained in emergency remote teaching? Lessons learned from the COVID-19 pandemic. Journal of Technology and Teacher Education, 28(2),

189-199.

https:/ / eric.ed.gov/?redir=https $\% 3 a \% 2 f \% 2$ flearntechlib.org $\% 2$ fprimary $\% 2 f p \% 2$ $\mathrm{f} 215995 \% 2 \mathrm{f}$

Wikramanayake, G. (2005, August). Impact of digital technology on education. In 24th National Information Technology Conference (pp. 82-91). Computer Society of Sri Lanka Colombo, Sri Lanka. https://www.researchgate.net/publication/216361364_Impact_of_Digital_Tech nology_on_Education

World Bank. (2020). Remote learning and COVID-19. The use of educational technologies at scale across an education system as a result of massive school closings in response to the COVID-19 pandemic to enable distance education and online learning. http:/ / documents.worldbank.org/curated/en/266811584657843186/pdf /Rapid-Response-Briefing-Note-Remote-Learning-and-COVID-19Outbreak.pdf

Xafis, V. (2020). What is inconvenient for you is life-saving for me: How health inequities are playing out during the COVID-19 pandemic. Asian Bioethics Review, 12, 223234. https://dx.doi.org/10.1007\%2Fs41649-020-00119-1 